\title{
ELS ONCOMICROBIÒTICS I LA INFLUÈNCIA DE LA MICROBIOTA EN LA CARCINOGÈNESI
}

\author{
Cont, Denisa Roxana; ${ }^{1}$ Miñana i Galbis, David ${ }^{2}$
}

Secció de Microbiologia, Departament de Biologia, Sanitat i Medi Ambient, Facultat de Farmàcia i Ciències de l'Alimentació, Universitat de Barcelona, Av. Joan XXIII, 27-31, 08028 Barcelona

\begin{abstract}
Microbiota result from a symbiotic union between a host and certain microorganisms, helping to preserve the balance between human health and disease, as they directly influence the host's metabolic, inflammatory and immune functions. The constant interaction between intestinal microbiota, the cells of the immune system, and the epithelium maintains intestinal homeostasis. This paper explains the scientific evidence supporting microbial influence in carcinogenesis, tumour progression, and the therapeutic efficacy of cancer drugs. Finally, it outlines the new challenges faced in therapeutics to enhance specific microbiota based on the therapeutic effectiveness needed.
\end{abstract}

Keywords: oncomicrobiotics, dysbiosis, microbiota, antitumoral therapy, cancer.

\section{Resumen}

La microbiota resulta de la unión simbiótica entre el huésped y ciertos microorganismos, lo que contribuye a preservar el balance entre salud y enfermedad, dado que influye directamente en las funciones metabólicas, inflamatorias e inmunitarias del huésped. La interacción constante entre la microbiota intestinal, las células del sistema inmunitario y el epitelio mantiene la homeostasis del intestino. En este estudio, se explicarán las evidencias científicas que demuestran la influencia de la microbiota en la carcinogénesis, en la progresión tumoral y en la respuesta a los diferentes tratamientos antineoplásicos. Finalmente, se detallarán los nuevos retos en terapéutica con el objetivo de optimizar la microbiota en función de la efectividad terapéutica requerida.

Palabras clave: oncomicrobióticos, disbiosis, microbiota, terapia antitumoral, cáncer.

\section{Resum}

La microbiota resulta de la unió simbiòtica entre l'hoste i certs microorganismes, i contribueix a preservar el balanç entre salut i malaltia, atès que influeix directament en les funcions metabòliques, inflamatòries i immunitàries de l'hoste. La interacció constant entre la microbiota intestinal, les cèllules del sistema immunitari i l'epiteli manté l'homeòstasi de l'intestí. En aquest estudi s'expliquen les evidències científiques que demostren la influència de la microbiota en la carcinogènesi, en la progressió tumoral i en la resposta als diferents tractaments antineoplàstics. Finalment, es detallen els nous reptes en terapèutica amb l'objectiu d'optimitzar la microbiota en funció de l'efectivitat terapèutica requerida.

Paraules clau: oncomicrobiòtics, disbiosi, microbiota, teràpia antitumoral, càncer.

\footnotetext{
${ }^{1}$ Graduada en Farmàcia per la Universitat de Barcelona (dcontcon7@alumnes.ub.edu).

${ }^{2}$ Professor Agregat en Microbiologia (davidminyana@ub.edu).
} 


\section{Introducció}

Formant part del cos humà, diferenciem un ecosistema microbià compost per bacteris, arqueus, protozous, fongs i virus (Havel, Chowell i Chan, 2019; Li et al., 2019). Les zones del cos més colonitzades són les que estan en contacte amb l'exterior: pell, tracte gastrointestinal, cavitat oral i tracte genitourinari (Markowski et al., 2019). En les diferents zones del cos es creen ecosistemes microbians que difereixen entre ells tant qualitativament com quantitativa; dit d'una altra manera, les espècies bacterianes de cada localització són diferents i, indirectament, les funcions metabòliques també ho són (Markowski et al., 2019). Aquest ecosistema influeix en la salut de l'hoste per la capacitat que té d'intervenir en el metabolisme, en el sistema immunitari i en els processos inflamatoris d'aquest (Ahmed i Umar, 2018).

Entre el cos humà i la microbiota s'estableix una relació de simbiosi mutualista que beneficia ambdues parts. Un dels principals avantatges que obtenim és la protecció enfront de la invasió de patògens externs. A més, també ajuden en el procés de metabolització de xenobiòtics i en la síntesi de les vitamines B i K (Ahmed i Umar, 2018; Li et al., 2019; Raza et al., 2019). En els animals als quals se'ls ha eliminat la microbiota, s'ha vist que funcionalment són més immadurs i susceptibles a infeccions (Roy i Trinchieri, 2017; Raza et al., 2019).

Un desequilibri en la microbiota pot comportar que certs bacteris comensals creixin de manera descontrolada i adquireixin un comportament patogènic, raó per la qual se'ls anomena patobionts (Roy i Trinchieri, 2017). De fet, la invasió per microorganismes patògens es dona amb més facilitat en cas de tenir la microbiota alterada (Li et al., 2019).

En aquest treball de revisió s'estudiarà la relació entre la microbiota i el sistema immunitari, la influència de la microbiota en la carcinogènesi i la quimioteràpia antitumoral, i com els oncomicrobiòtics poden ser útils en la lluita contra el càncer.

\section{Metodologia}

Per a aquesta revisió s'ha fet una cerca bibliogràfica exhaustiva a través de fonts primàries (articles científics), secundàries (articles de revisió) i terciàries (pàgines web) des del febrer del 2019 fins al maig del mateix any. Les bases de dades utilitzades han estat PubMed i Scopus, des d'on s'ha pogut accedir als articles gràcies a les facilitats proporcionades pel Centre de Recursos per a l'Aprenentatge i la Investigació (CRAI) i el Collegi de Farmacèutics de Barcelona (COFB).

Un cop determinat quin podria ser l'enfocament general del treball, es va procedir a establir una base de coneixements generals sobre els quals es pogués aprofundir posteriorment. Després es va iniciar una cerca sobre temes més concrets, com ara la relació de la microbiota amb el càncer, la modulació de la resposta immunitària i l'efectivitat terapèutica dels fàrmacs utilitzats en immunoteràpia i quimioteràpia antitumorals. Les principals paraules clau utilitzades en la cerca d'informació van ser: "oncomicrobiotics", "cancer", "dysbiosis", "antitumoral therapies" i "microbiota".

\section{Resultats i discussió}

\subsection{Microbiota i sistema immunitari}

Partint de la base que els bacteris localitzats en la microbiota poden influir en moltes funcions fisiològiques de l'hoste, no sorprèn que també modifiquin el sistema immunitari tant a nivell local com sistèmic (Havel, Chowell i Chan, 2019; Li et al., 2019). De manera local, modulen la resposta immunitària mitjançant l'alliberament de metabòlits procedents del seu metabolisme, on els àcids grassos de cadena curta (SCFA) o els àcids grassos volàtils (VFA) són els més rellevants (Rooks i Garrett, 2016; Ahmed i Umar, 2018; Raza et al., 2019). 
Aquests s'obtenen a partir de la fibra de la dieta i estimulen l'alliberament d'immunoglobulina A (IgA), encarregada d'evitar l'adhesió de bacteris patògens a les cèllules epitelials per tal de preservar la integritat de la barrera intestinal (Li et al., 2019). A més, els SCFA eviten el sobrecreixement de patògens gramnegatius, neutralitzen processos proinflamatoris, promouen l'apoptosi de cèlllules tumorals i són utilitzats com a font d'energia pels colonòcits i altres bacteris (McQuade et al., 2019).

El mecanisme d'acció dels SCFA es basa a inhibir l'activitat de les histones deacetilases, uns enzims implicats en l'eliminació del grup acetil dels residus de lisina de les histones, que incrementen així la seva càrrega positiva i, en conseqüència, la seva afinitat per l'ADN. Aquest procés en condensa l'estructura i n'impedeix la transcripció. Dit d'una altra manera, els SCFA afecten la regulació epigenètica perquè silencien algunes regions genètiques (Rooks i Garrett, 2016; Li et al., 2019).

Així mateix, la immunitat local és modulada pels receptors que reconeixen patrons (PRR), encarregats de distingir patrons moleculars associats a patògens (PAMP). Els PAMP són els responsables de la maduració de les cèlllules presentadores d'antígens (APC), incloent-hi les cèlllules dendrítiques. Un cop han madurat, entren als ganglis limfàtics del mesenteri amb l'objectiu de madurar els limfòcits T CD4+ immadurs i convertir-los en limfòcits T $\mathrm{CD}^{+}{ }^{+}$reguladors $\left(\mathrm{T}_{\text {reg }}\right)$ i limfòcits T CD4 ${ }^{+}$collaboradors o helpers (Th17) (Li et al., 2019).

Els limfòcits T CD4+ activats ajuden al manteniment de l'homeòstasi intestinal i, a més, els limfòcits $\mathrm{T}_{\text {reg }}$ modulen la tolerància de la mucosa gràcies a la producció de citocines immunosupressores. $S^{\prime}$ ha evidenciat una comunicació directa entre els bacteris de la microbiota i els limfòcits $\mathrm{T}_{\text {reg }}$ desencadenada pels SCFA. En definitiva, certs metabòlits sintetitzats pels bacteris tenen un paper clau en la tolerància i el manteniment de la microbiota intestinal (Rooks i Garrett, 2016).

Ara bé, la microbiota també pot arribar a modular la resposta immunitària sistèmica. Les cèllules dendrítiques entren als nodes limfàtics del mesenteri per presentar antígens específics dels bacteris de la microbiota als limfòcits T i B. Aquests limfòcits, en trobar-se davant una infecció causada per microorganismes o epítops similars, tindran avantatge en el moment de resoldre el problema (Li et al., 2019).

\subsection{Microbiota gastrointestinal}

En el tracte intestinal trobem, aproximadament, bacteris, la gran majoria dels quals tenen una relació simbiòtica amb l'hoste (Ahmed i Umar, 2018). Gràcies als avenços en les tecnologies genòmiques d'alt rendiment s'han pogut seqüenciar i determinar, d'una manera molt més precisa, la composició i les funcions de la microbiota intestinal humana (Faith et al., 2013)

A nivell intestinal trobem un microsistema complex format per bacteris endògens, patògens, cèlllules epitelials, complexos enzimàtics, mucus, sals biliars, aliments, etc. En condicions fisiològiques normals, aquest ecosistema és estable i treballa conjuntament per mantenir l'homeòstasi de tot el cos. Tanmateix, si l'equilibri es veu afectat, podria desencadenar un problema de salut (Roy i Trinchieri, 2017; Ahmed i Umar, 2018).

Així, algunes de les funcions més importants que la microbiota intestinal duu a terme són: $a$ ) l'estimulació, el desenvolupament i la regulació del sistema immunitari, $b$ ) l'obstaculització de la invasió de microorganismes patògens externs, $c$ ) el manteniment de la integritat de la mucosa intestinal, i $d$ ) l'absorció de nutrients, la síntesi de vitamines i la participació en el metabolisme de carbohidrats, àcids biliars i hormones (Roy i Trinchieri, 2017).

Quant a la seva composició, aproximadament el $90 \%$ de la microbiota intestinal d'una persona adulta sana està formada per bacteris procedents de dos fílums: Firmicutes i Bacteroidetes (Wong et al., 2019). El 10\% restant correspon a bacteris dels fílums següents: "Proteobacteria, Tenericutes, Deffibacteres, Verrucomicrobia i Fusobacteria" (Faith et al., 2013; Ahmed i Umar, 2018) 


\subsection{Microbiota intestinal i càncer}

Temps enrere ja s'havia relacionat la microbiota amb l'aparició i la progressió d'una gran varietat de càncers, sobretot epitelials. Es va observar que un procés infecciós crònic, tant víric com bacterià, afectava els processos cellulars normals i, per tant, contribuïa a la carcinogènesi. Per exemple, existeixen evidències respecte a la relació del càncer gàstric amb la presència d'Helicobacter pylori, i a la del càncer de còlon amb la presència de Fusobacterium nucleatum (McQuade et al., 2019; Raza et al., 2019).

El bacteri Helicobacter pylori contribueix a la carcinogènesi gàstrica mitjançant, per una banda, la síntesi de citotoxines capaces de pertorbar les vies de senyalització d'apoptosi i d'autofàgia i, per l'altra, la modulació de les vies de senyalització de processos proliferatius com, per exemple, la via de la $\beta$-catenina i de la Ras/MEK/ERK. (Ras/ Mitogen Activated Kinase Kinase / Extracellular signal-Regulated Kinase). A més, a conseqüència del procés inflamatori crònic s'activa la senyalització del factor nuclear kappa B (NF-kB) i la producció de IL-8 (McQuade et al., 2019; Raza et al., 2019; Wong et al., 2019). Per tant, de manera general, tendim dos mecanismes a través dels quals es dona la carcinogènesi (Li et al., 2019):

a) Mecanisme directe: síntesi de metabòlits tòxics o carcinògens (taula 1).

b) Mecanisme indirecte: modulació de processos inflamatoris i immunosupressors.

Ara bé, hi ha estudis que demostren la capacitat anticancerosa de la microbiota pel fet de potenciar la immunitat de l'hoste i d'altres que han permès comprovar que hi ha una relació dosidependent entre els antibiòtics i el risc de carcinogènesi (Havel, Chowell i Chan, 2019; Li et al., 2019).

TAULA 1. METABÒLITS BACTERIANS RELACIONATS AMB CÀNCER (Raza et al., 2019).

\begin{tabular}{|c|c|c|c|}
\hline Toxin/Metabolite & Mode of action & Bacterial specie & References \\
\hline FadA & $\begin{array}{l}\text { Adhesin which is located on the surface of bacterial } \\
\text { specie activates } \beta \text {-catenin and promotes inflammatory } \\
\text { responses }\end{array}$ & Fusobacterium nucleatum & Garrett (2015) \\
\hline CagA & Increases cellular proliferation by activating $\beta$-catenin & Helicobacter pylori & Garrett (2015) \\
\hline Trimethylamine-N-oxide (TMAO) & Utilization of L-carnitine for production of TMAO & Clostridium sp. & Faith et al. (2013) \\
\hline Cytolethal distending toxin (Cdt) & Promotes genomic instability & Epsilonproteobacteria sp. & Gagnière et al. (2016) \\
\hline $\mathrm{Btf}$ & $\begin{array}{l}\text { Induces oxidative DNA damage by increasing ROS } \\
\text { levels }\end{array}$ & Bacteroides fragilis & Boleij et al. (2014) \\
\hline Butyrate & $\begin{array}{l}\text { Promotion of cellular proliferation and induction of } \\
\text { apoptotic cell death }\end{array}$ & Bifidobacterium sp. & Belcheva et al. (2014) \\
\hline Deoxycholic acid & Activation of $\beta$-catenin mediated signaling cascades & Clostridium sp. & Ha and Park (2010) \\
\hline Fragilysin & Activation of $\beta$-catenin mediated signaling cascades & Bacteroides fragilis & Sears et al. (1995) \\
\hline Lithocholic acid & Induction of tumor metastasis & Bacteroides fragilis & Baek et al. (2010) \\
\hline
\end{tabular}

Així mateix, els bacteris intestinals influeixen en la malaltia de l'empelt contra l'hoste (GVHD) després del trasplantament al-logènic de cèlllules mare hematopoètiques. La GVHD sol produir-se després d'un trasplantament de medullla òssia o de cèllules mare on l'hoste percep les cèlllules del donant com a estranyes i les ataca (Helmink et al., 2019; Li et al., 2019; Misch i Safdar, 2019).

L'administració d'antibiòtics sistèmics d'ampli espectre abans del trasplantament es correlaciona amb un increment de la mortalitat del pacient com a conseqüència de la GVHD. Es pensa que podria ser per l'erradicació d'espècies protectores de la microbiota, com, per exemple, Faecalibacterium spp., Ruminococcus spp., Lactobacillus spp. i Blautia spp. (Li et al., 2019; McQuade et al., 2019). Finalment, la desestabilització de la microbiota pot comportar inestabilitat intestinal que faciliti la translocació bacteriana a través de la barrera epitelial i desencadeni un procés infecciós sistèmic (McQuade et al., 2019). 
Edusfarm 11-12 (2019-2020), 93-110

ISSN: 1886-6271

\subsubsection{Càncer colorectal}

El càncer colorectal (CRC) o càncer de còlon és una patologia neoplàstica localitzada al còlon i/o al recte (Jin et al., 2018). L'espècie bacteriana que més s'ha relacionat amb el càncer colorectal és Fusobacterium nucleatum. El seu mecanisme d'acció consisteix en l'evasió de les cèlllules epitelials a través de la proteïna adhesina FadA, a més de la modificació de la ruta de senyalització $\beta$-catenina i Wnt, que indueix processos inflamatoris i carcinògens (McQuade et al.,2019).

Certs estudis, realitzats en ratolins amb tumors induits i en pacients amb CRC, van constatar que hi havia una modificació en la seva microbiota intestinal. Els canvis taxonòmics i funcionals poden evolucionar cap a alteracions fisiològiques $\mathrm{i}$, si el problema no se soluciona, patologies neoplàstiques com el càncer de còlon (Ahmed i Umar, 2018; Jin et al., 2018).

Els processos mitjançant els quals es passa d'un epiteli saludable a un carcinoma encara no es coneixen amb exactitud. Tot i això, l'alteració de la microbiota (disbiosi) localitzada a nivell intestinal podria generar metabòlits tòxics i provocar la disminució del mucus i de les funcions de barrera de l'epiteli, fets que es relacionen directament amb el dany genètic responsable de l'aparició del tumor (figura 1).

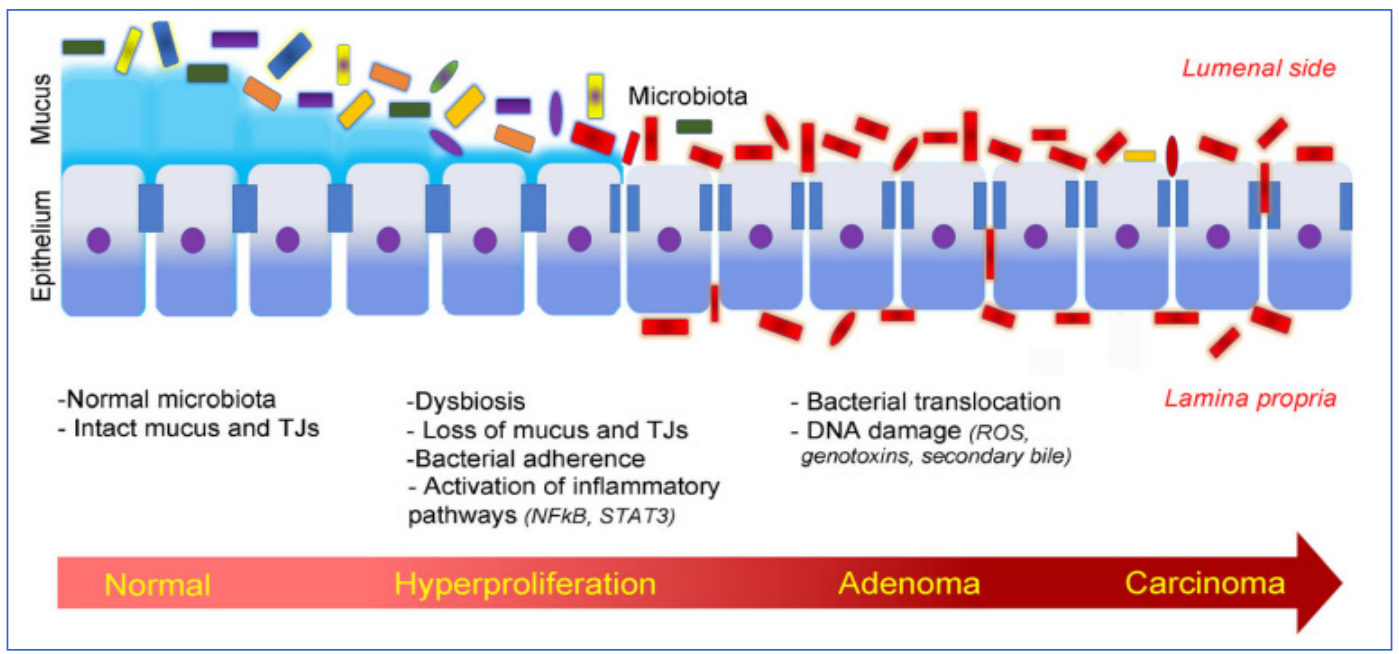

Figura 1. Formació del carcinoma colorectal (Ahmed i Umar, 2018).

Per tant, es podria dir que el desenvolupament i la progressió del CRC està relacionat amb processos de disbiosi, inflamació crònica de l'epiteli, resposta del sistema immunitari, alteració de la dinàmica de les cèlllules mare, síntesi de metabòlits tòxics i alteració del metabolisme de l'hoste (Ahmed i Umar, 2018).

\subsubsection{Disbiosi}

La disbiosi es defineix com un desequilibri en l'estructura i la composició de la microbiota que permet el sobrecreixement de microorganismes patògens (Ahmed i Umar, 2018; Raza et al., 2019). Les causes que desencadenen la seva aparició poden ser genètiques, dietètiques, l'ús d'antibiòtics i la inflamació crònica (Ahmed i Umar, 2018; Helmink et al., 2019; Raza et al., 2019).

En els pacients amb CRC es van veure incrementades les espècies bacterianes pertanyents als gèneres Parvimonas, Peptostreptococcus, Fusobacterium i Porphyromonas (Ahmed i Umar, 2018).

Un altre factor important que cal tenir en compte és la dieta, principalment per la producció de SCFA obtinguts a través de la metabolització de la fibra no digerible de la dieta. Els SCFA tenen un paper fonamental a dificultar el creixement de bacteris proinflamatoris i a mantenir la microbiota a l'intestí, és a dir, a adquirir una determinada tolerància (Ahmed i Umar, 2018). 
En pacients amb una dieta baixa en fibra i alta en greixos, com ara els obesos, s'ha vist que hi ha acumulació d'un determinat metabòlit, l'àcid desoxicòlic, inductor de la inflamació i del càncer. Realment la dieta es podria considerar un factor important que cal tenir en compte, ja que en molts països el patró d'alimentació es basa en carns vermelles processades, aliments greixosos i refinats, alcohol, sal, etc.; aliments proinflamatoris que alteren la microbiota i són carcinògens (Bultman, 2016; Ahmed i Umar, 2018).

\subsubsection{Pèrdua de la funció de la barrera epitelial}

L'epiteli intestinal està format per una única capa de cèlllules epitelials que en situacions normals estan protegides de la llum intestinal per una doble capa de mucus secretada per les cèlllules caliciformes. Contràriament, en un estat patològic la mucositat i les unions entre les cèllules epitelials es debiliten i faciliten l'entrada de bacteris a través de l'epiteli, fet que desencadena inflamació crònica (Ahmed i Umar, 2018).

Una hipòtesi explica que les toxines alliberades pels bacteris podrien interaccionar amb els receptors de tipus Toll (Toll-like receptors, TLR), fet que activaria la proteïna MyD88 i desencadenaria la producció de citocines proinflamatòries, com la IL-23. Certs estudis han demostrat que la senyalització de la proteïna adaptadora MyD88, els receptors TLR i la família IL-1R tenen un paper essencial en la carcinogènesi (Ahmed i Umar, 2018; Raza et al., 2019).

\subsubsection{Inflamació crònica}

En situacions no patològiques, els bacteris constituents de la microbiota intestinal tenen un paper imprescindible a suprimir la inflamació induïda per IL-10 gràcies al manteniment d'uns nivells adequats de limfòcits $\mathrm{T}_{\text {reg. }}$ Si aquest sistema es desequilibra, podria entrar en un procés d'inflamació constant, que seria un factor de risc per a l'aparició d'un carcinoma colorectal (Ahmed i Umar, 2018).

Els pacients amb malaltia inflamatòria intestinal tenen un major risc de desenvolupar una patologia neoplàstica. Així mateix, en aquests pacients s'han detectat colonitzacions bacterianes intestinals protagonitzades per Enterobacteriaceae i Mycobacterium spp.

De fet, en gran part dels pacients amb càncer de còlon predomina Escherichia coli en la seva microbiota; no obstant això, s'ha demostrat que el bacteri no influeix en la formació del tumor per si sol, sinó que necessita un procés inflamatori previ (Ahmed i Umar, 2018).

Pel que fa als mecanismes d'aparició del CRC, se n'han descrit dos. D'una banda, la microbiota i els seus metabòlits poden interaccionar amb els receptors TLR i activar la ruta de senyalització de l'NF-kB, complex enzimàtic implicat en la supressió de l'apoptosi i la potenciació dels processos inflamatoris.

D'altra banda, s'incrementa la producció d'espècies reactives de l'oxigen (ROS) i del nitrogen, que tenen una acció directa en els processos d'estrès oxidatiu, proliferació anòmala, alteracions genètiques i càncer (Ahmed i Umar, 2018).

\subsubsection{Oncomicrobis}

Els oncomicrobis són els bacteris amb capacitat d'alterar l'ADN i els processos cellulars de l'hoste fins al desenvolupament de càncer. Existeixen diferents bacteris que ja s'han considerat oncomicrobis intestinals tenint en compte els resultats dels últims estudis experimentals (Ahmed i Umar, 2018).

Així, se va identificar la presència d'Escherichia coli i Bacteroides fragilis en biofilms intestinals de pacients diagnosticats de poliposi adenomatosa familiar. D'una banda, Escherichia coli sintetitza una toxina mutàgena i oncogènica anomenada colibactina. De l'altra, la toxina de Bacteroides fragilis 
(BFT) activa una cascada inflamatòria on IL-17R, NF-kB i Stat3 s'encarreguen d'interaccionar amb l'epiteli intestinal. En humans, la colonització per Bacteroides fragilis està directament relacionada amb el carcinoma colorectal (Ahmed i Umar, 2018).

Un altre oncomicrobi descrit és Citrobacter rodentium. Aquest bacteri gramnegatiu és capaç de regular la ruta de senyalització de $\beta$-catenina, NF-kB i Notch, fet que induirà la proliferació celllular i incrementarà la susceptibilitat a desencadenar un procés carcinogen (Ahmed i Umar, 2018).

Altrament, Fusobacterium nucleatum és un bacteri comensal oral que també s'ha relacionat amb adenomes humans, ja que en estudis amb ratolins s'ha evidenciat que incrementa la mida del tumor i disminueix considerablement el percentatge de supervivents. Fusobacterium nucleatum influeix en la carcinogènesi mitjançant diferents mecanismes (Ahmed i Umar, 2018; Wong et al., 2019):

- Regula l'expressió del promotor cancerigen miR-21 (també anomenat oncomiR) per la via de senyalització TLR4/MyD88/NF-kB.

- L'adhesina FadA del bacteri s'uneix a la cadherina-E expressada a nivell epitelial, fet que activa la senyalització de la $\beta$-catenina i incrementa l'expressió de gens oncogènics i proinflamatoris.

- La proteïna Fap 2 (Fatty-acid-binding protein 2) quan s'uneix al receptor inhibidor dels limfòcits T TIGIT ( $T$ cell immunoreceptor with IG and ITIM domains) aconsegueix bloquejar l'activació dels limfòcits T i NK i, així, evita l'erradicació del tumor.

Les conclusions que es deriven dels diferents estudis són, per una banda, que les espècies bacterianes com Escherichia coli, Klebsiella pneumoniae i altres Enterobacteriaceae contenen una regió genòmica $p k s$ d'on es transcriu la proteïna colibactina encarregada de produir dany genètic.

Per l'altra, Fusobacterium spp., Bacteroides fragilis i Porphyromonadaceae també causen dany genètic, inestabilitat genòmica i activació de les rutes de senyalització proinflamatòries. A més, s'ha descrit que Streptococcus gallolyticus subsp. gallolyticus és més abundant en pacients amb CRC (Ahmed i Umar, 2018).

\subsection{Quimioteràpia antitumoral}

\subsubsection{Definició i classificació}

La quimioteràpia antitumoral consisteix en l'administració de medicaments sistèmics amb la finalitat de destruir les cèlllules tumorals. Forma part dels quatre tipus de tractaments antineoplàstics existents, juntament amb la cirurgia, la radioteràpia i la immunoteràpia. Els agents quimioteràpics antitumorals es classifiquen en funció del seu mecanisme d'acció, com es mostra a continuació (Roy i Trinchieri, 2017; Raza et al., 2019):

- Agents que alteren l'ADN:

- Agents alquilants: mostasses nitrogenades (ciclofosfamida [CTX]), derivats del platí (cisplatí, oxaliplatí, etc.) i nitrosourees.

- Antimetabòlits: anàlegs de bases puríniques, inhibidors d'adenosina-desaminasa, anàlegs de bases pirimidíniques (gemcitabina, etc.) i inhibidors de l'àcid fòlic (metotrexat).

- Antibiòtics citotòxics: doxorubicina, etc.

- Inhibidors de la topoisomerasa I II: irinotecan, topotecan, etopòsid, etc.

- Agents que es fixen a la tubulina: alcaloides de la vinca i taxans.

- Altres: hidroxiurea i $L$-asparaginasa. 
Algunes espècies bacterianes que formen part de la microbiota aconsegueixen modificar el metabolisme, la farmacocinètica, la toxicitat i l'eliminació dels quimioteràpics utilitzats en el tractament del càncer. Per exemple, Mycoplasma hyorhinis i certs proteobacteris poden desactivar la gemcitabina i obtenir així una resistència al tractament antineoplàstic (Markowski et al., 2019).

\subsubsection{Influència en el metabolisme dels fàrmacs}

La microbiota pot arribar a modificar la farmacocinètica, l'activitat i la toxicitat dels fàrmacs quimioteràpics, cosa que aconsegueix influint en el metabolisme (figura 2) (Roy i Trinchieri, 2017; Raza et al., 2019).

La microbiota intestinal afecta directament l'absorció i la biodisponibilitat dels fàrmacs, ja sigui per les biotransformacions que pateixen els quimioteràpics en arribar al tracte intestinal a través de la via oral, ja sigui per la reactivació d'aquests un cop han estat metabolitzats i neutralitzats pel fetge.

En general, s'ha demostrat que més de quaranta fàrmacs pateixen transformacions, però en el cas concret dels antitumorals només n'hi ha tres casos confirmats: nitroreducció del misonidazole (radiofàrmac), hidròlisi del metotrexat i desconjugació de l'irinotecan (Roy i Trinchieri, 2017).

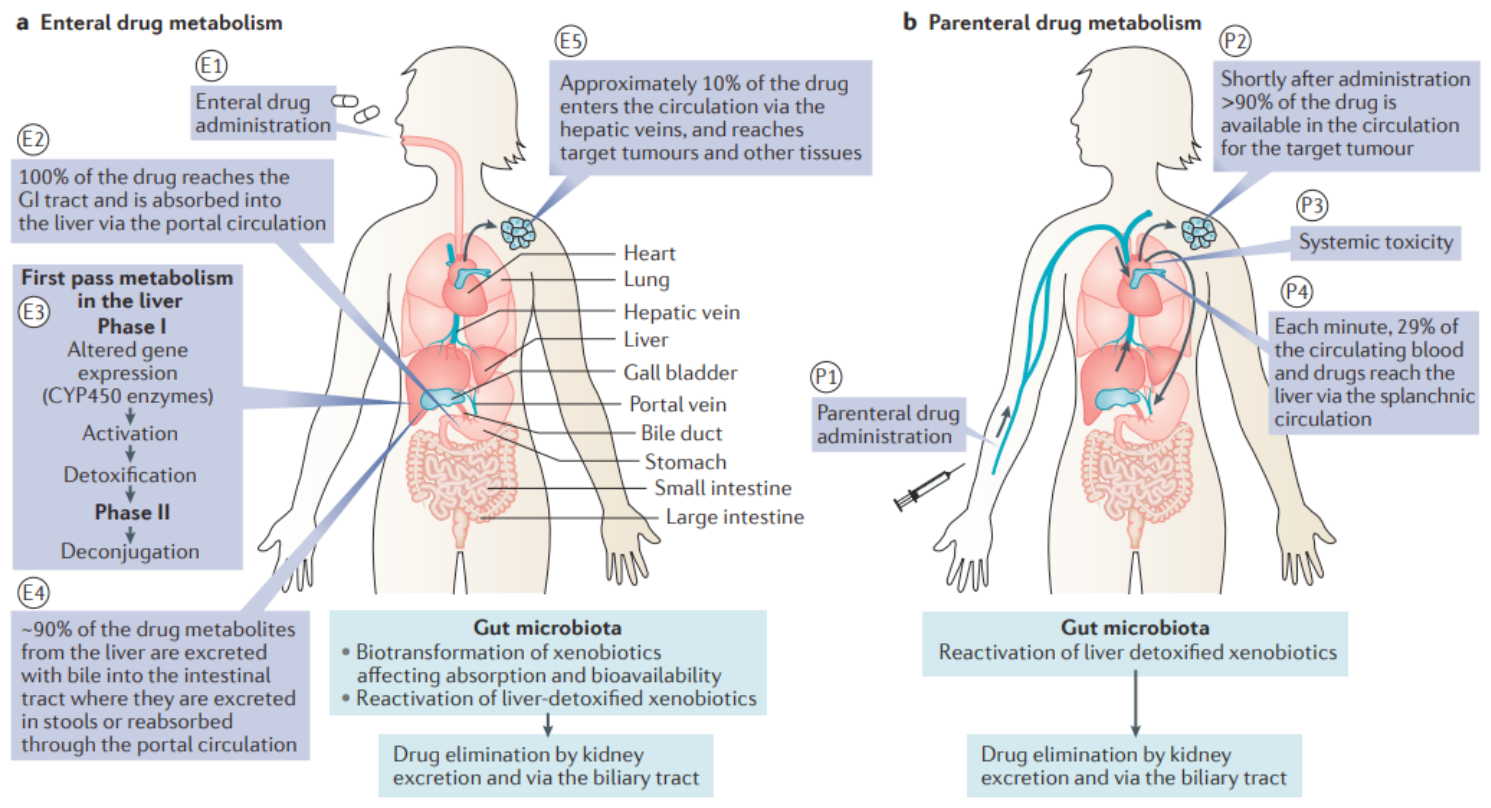

Figura 2. Influència de la microbiota en el metabolisme dels quimioteràpics (Roy i Trinchieri, 2017).

Si bé és cert que la microbiota afecta directament el metabolisme dels fàrmacs, també ho fa indirectament a través de la modulació de l'expressió de gens de la barrera epitelial local i d'òrgans distals, com el fetge. En un experiment realitzat en ratolins sense microbiota, estaven sobreexpressats els gens que codifiquen els receptors sensibles a xenobiòtics i certs factors de transcripció com serien el receptor constitutiu d'androstà $(C A R)$, el gen p450 oxidoreductasa $(P O R)$, regulat pel receptor CAR, el receptor aril-hidrocarbur $(A h R)$, el receptor activat per proliferadors de peroxisomes (Ppara) i el factor 1, associat al factor nuclear eritroide 2 (Nrf2). Aquests canvis en l'expressió gènica conclouen que hi ha un increment de la velocitat de metabolització dels xenobiòtics (Roy i Trinchieri, 2017). 
Edusfarm 11-12 (2019-2020), 93-110

ISSN: 1886-6271

\subsubsection{Agents alquilants: ciclofosfamida}

La ciclofosfamida (CTX) és un quimioteràpic del grup dels agents alquilants i en els pacients amb càncer tractats amb aquest fàrmac s'han observat dos fets importants (Roy i Trinchieri, 2017; McQuade et al., 2019; Raza et al., 2019):

- Increment de la permeabilitat de l'epiteli intestinal, que afavoreix la translocació de la microbiota als nodes limfàtics mesentèrics.

- Alteració de la composició de la microbiota en un període inferior a una setmana. Es veu reduïda l'abundància de certes espècies, mentre que hi ha un increment dels bacteris grampositius, com Enterococcus hirae i Lactobacillus johnsonii.

La translocació bacteriana cap als nodes limfàtics condueix a un augment de la ràtio limfòcits $\mathrm{T} \mathrm{CD}^{+} /$limfòcits $\mathrm{T}$ reguladors $\left(\mathrm{T}_{\text {reg }}\right)$ en el tumor. A més, es dona l'activació de la resposta immunitària dels limfòcits T 17 col-laboradors patogènics (pTh17) i dels limfòcits Th1 de memòria.

La resposta dels limfòcits pTh17 i l'efectivitat terapèutica de la CTX es veuen disminuïdes en els ratolins sense microbiota o tractats amb antibiòtics d'ampli espectre. No obstant això, l'èxit del tractament es podria restablir amb la transferència de limfòcits pTh17 d'un donant específic (Pitt et al., 2016; Roy i Trinchieri, 2017; Helmink et al., 2019).

\subsubsection{Agents alquilants: derivats del platí}

Com la majoria dels quimioteràpics antitumorals, també són fàrmacs tòxics per a totes les cèl·lules, tumorals o no, que tenen una taxa de divisió molt elevada; la mucosa intestinal en seria un exemple. Durant el tractament antineoplàstic, la barrera epitelial intestinal perd funcionalitat, cosa que afavoreix la penetració dels bacteris comensals i patògens als nodes limfàtics mesentèrics i, posteriorment, al sistema sanguini, i això desencadena un procés inflamatori sistèmic i septicèmia (Roy i Trinchieri, 2017).

L'efectivitat terapèutica de l'oxaliplatí i el cisplatí es veu greument afectada en els ratolins sense microbiota i en els que se'ls han administrat antibiòtics d'ampli aspecte. Aquest fet s'explica de la manera següent: els efectes citotòxics dels compostos de platí són causats per les espècies reactives de l'oxigen (ROS) sintetitzades per les cèl-lules mieloides infiltrades en el tumor a través de la via NADPH oxidasa 2 (NOX2). En absència de microbiota, aquesta ruta sintètica no s'activa, però l'administració de probiòtics amb Lactobacillus acidophilus s'ha vist que restaura l'èxit terapèutic del cisplatí (Roy i Trinchieri, 2017).

Es pensa que el principal mecanisme d'acció a través del qual la microbiota o els probiòtics amb Lactobacillus acidophilus activen la síntesi de ROS per part de les cèllules mieloides localitzades en el tumor, consisteix en la modulació de la ruta de senyalització de la resposta primària de diferenciació mieloide 88 (MYD88) pels receptors que reconeixen patrons (PRR). Tot i això, no es coneix amb exactitud quins són els receptors específics que s'hi troben involucrats (Roy i Trinchieri, 2017).

En altres experiments amb ratolins sense microbiota, l'efecte genotòxic i citotòxic dels compostos de platí s'ha vist reduït considerablement. Aquest descobriment fa pensar que els microorganismes presents en la microbiota tenen un paper fonamental en la modulació de l'efecte citotòxic i en la resposta immunitària adaptativa a través de mecanismes indirectes (Roy i Trinchieri, 2017).

\subsubsection{Inhibidors de la topoisomerasa I: irinotecan}

L'irinotecan és un quimioteràpic administrat per via intravenosa i utilitzat en el tractament del càncer de còlon, entre d'altres. És transformat en la seva forma activa SN-38 gràcies a les carboxilesterases del fetge i altres teixits intestinals. 
La seva desactivació i conversió en SN-38-G es dona al fetge mitjançant la UDP-glucuroniltransferasa. És aquí on la microbiota entra en joc, ja que les $\beta$-glucuronidases bacterianes poden reactivar l'SN-38-G i convertir-lo en SN-38, fet que provocarà toxicitat intestinal i greus episodis de diarrea (Roy i Trinchieri, 2017; McQuade et al., 2019; Raza et al., 2019).

En ratolins tractats amb irinotecan s'ha vist incrementada l'abundància de bacteris pertanyents al gènere Clostridium clúster XI (reclassificats recentment com a Clostridioides dins la família Peptostreptococcaceae) i a la família Enterobacteriaceae, relacionats directament amb processos inflamatoris i canvis en la proporció de bacteris que expressen $\beta$-glucuronidases.

Finalment, en animals d'experimentació s'ha observat que l'ús d'antibiòtics contra bacteris productors d'aquests enzims o fàrmacs que els inhibeixen, reverteix ràpidament el procés inflamatori induït per l'irinotecan (Roy i Trinchieri, 2017).

\subsection{Immunoteràpia antitumoral}

La immunoteràpia és una teràpia biològica que consisteix a administrar substàncies que restaurin el funcionament correcte del sistema immunitari amb la finalitat de combatre patologies degeneratives, sistèmiques i neoplàstiques. Trobem diferents tipus d'immunoteràpia: anticossos monoclonals, immunoteràpies no específiques, teràpies amb virus oncolítics, teràpia amb limfòcits $\mathrm{T}$ i vacunes (Havel, Chowell i Chan, 2019).

\subsubsection{Inhibidors dels punts de control del sistema immunitari}

En determinats pacients amb càncer el sistema immunitari es troba suprimit, però pot ser reactivat amb teràpies immunològiques basades en anticossos monoclonals (Roy i Trinchieri, 2017). Un exemple d'aquestes teràpies seria el dels inhibidors dels següents punts de control del sistema immunitari (Havel, Chowell i Chan, 2019; Markowski et al., 2019):

- PD-1 (Programmed cell Death protein 1): proteïna de mort cellular programada 1.

- PD-L1 (Programmed cell Death Ligand 1): lligand 1 de mort cel-lular programada.

- CTLA-4 (Cytotoxic T-Lymphocyte Antigen 4): antigen 4 del limfòcit T citotòxic.

Els inhibidors dels punts de control del sistema immunitari (ICI) reben el nom d'anti-PD-1/ PD-L1 i anti-CTLA-4 (Havel, Chowell i Chan, 2019).

Les cèlllules presentadores d'antígens (APC) activen els limfòcits T per mitjà de la presentació d'un antigen específic. L'activació només té lloc si es reben dos senyals corresponents a la unió dels dos parells de receptors (Havel, Chowell i Chan, 2019):

- Senyal 1: complex d'histocompatibilitat principal (Major Histocompatibility Complex, MHC) d'APC amb el receptor del limfòcit T (T cell receptor, TCR).

- Senyal 2: proteïna CD80/CD86 de l'APC amb el CD28 del limfòcit T.

Un cop el limfòcit està activat, comença a expressar en la seva membrana els receptors PD-1 i CTLA-4 amb activitat autoinhibitòria. D'una banda, la unió entre el receptor CTLA-4 i la proteïna CD80/CD86 té molta més afinitat que no pas amb el CD28; en conseqüència, es dona una prevenció de l'estimulació contínua de limfòcits. El bloqueig del receptor CTLA-4 permet activar els limfòcits T en òrgans limfoides secundaris. D'altra banda, la interacció entre la PD-L1 i el seu receptor inhibeix la transducció de senyal. Si s'evita aquesta unió, es reforça la funció d'aquests limfòcits (figura 3) (Havel, Chowell i Chan, 2019). 
Els punts de control del sistema immunitari són reguladors, és a dir, inhibeixen o estimulen el sistema. Són imprescindibles en el procés de tolerància; dit d'una altra manera, prevenen de l'atac a cèlllules pròpies. Els tumors poden adquirir la capacitat de protegir-se davant la resposta immunitària actuant sobre aquests punts de control (Havel, Chowell i Chan, 2019; Li et al., 2019).

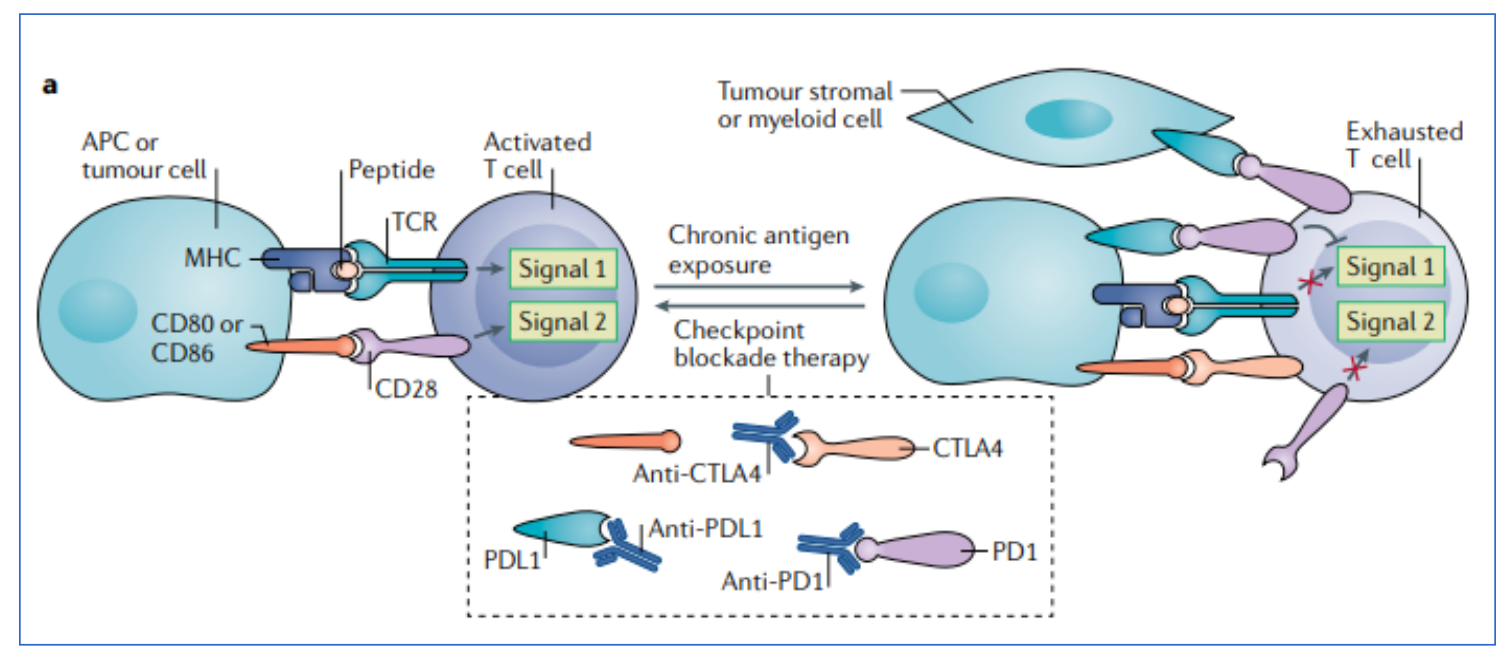

Figura 3. Mecanisme d'acció dels ICI (Havel, Chowell i Chan, 2019).

\subsubsection{Anti-PD-1/PD-L1}

En un experiment dut a terme en ratolins medicats amb anti-PD-1/PD-L1 es va observar una efectivitat significativa en els que presentaven Bifidobacterium spp. (sobretot, B. breve, B. longum i B. adolescentis) en la microbiota intestinal. No només la resposta al tractament era millor, sinó que el creixement del tumor era considerablement més lent.

Als ratolins amb una microbiota empobrida se'ls van administrar probiòtics amb Bifidobacterium spp., fet que va incrementar l'efectivitat terapèutica. El mecanisme d'acció consistia en la millora de la maduració de les cèlllules dendrítiques, cosa que permetia una activitat més específica dels limfòcits T CD8 ${ }^{+}$(Roy i Trinchieri, 2017; Li et al., 2019).

En un altre estudi es van comparar dos grups de pacients amb tumors epitelials tractats amb anti-PD-1/PD-L1. A un dels grups se li van administrar antibiòtics seguint el protocol rutinari, mentre que a l'altre grup, no. La supervivència global i l'aturada de l'evolució del tumor van ser significativament més favorables en els pacients que no havien estat sotmesos a un tractament antibiòtic (Routy et al., 2018; Elkrief et al., 2019; Havel, Chowell i Chan, 2019; Li et al., 2019). En la seqüenciació metagenòmica de les mostres fecals dels pacients que sí que responien correctament al tractament amb inhibidors de la proteïna PD-1, es va veure un increment d'espècies pertanyents als gèneres Akkermansia (fílum Verrucomicrobia) i Alistipes (fílum Bacteroidetes) (Routy et al., 2018; Li et al., 2019).

Per confirmar si aquests gèneres tenien alguna relació amb la millor resposta als ICI, es va realitzar en ratolins un trasplantament de microbiota fecal (FMT) humana, provinent de pacients que havien respost correctament al tractament, just abans d'administrar els anti-PD-1. En un altre grup de ratolins es va seguir el mateix procediment, però la microbiota fecal humana trasplantada provenia de pacients que no van respondre adequadament al tractament. El resultat va ser una potenciació de la immunitat envers el tumor en els ratolins amb FMT de pacients que havien respost millor al tractament antineoplàstic (Li et al., 2019).

En conseqüència, en totes les proves realitzades s'ha pogut correlacionar Akkermansia muciniphila amb un increment de les cèlllules immunològiques, que s'infiltren en el tumor per la mobilització de limfòcits T CD4+ (colllaboradors) amb receptors CCR9+ CXCR3+. No només això, sinó que la 
relació de limfòcits T CD4+ que maduren i esdevenen limfòcits T CD4+FoxP3+ es va veure afavorida (Routy et al., 2018).

Tots els limfòcits mencionats anteriorment tenen un paper fonamental en l'erradicació del tumor. Per una banda, el CCR9+ és un receptor de quimosina integrat en la membrana dels limfòcits T madurs i immadurs, que s'expressa molt més en el timus i a nivell intestinal. D’altra banda, el CXCR3 + també és un receptor de quimosina predominant en els limfòcits T, però, a més, es troba en limfòcits B i cèlllules NK (Natural Killer). Tots dos receptors de quimosina indueixen l'activació de les cèlllules del sistema immunitari. Pel que fa a FoxP3+, és una proteïna específica dels limfòcits Treg (cèlllules T reguladores) que presenta una capacitat supressora del desenvolupament tumoral (Li et al., 2019).

Als pacients amb melanoma metastàtic que responien positivament al tractament amb antiPD-1 se'ls van veure incrementades en la microbiota espècies bacterianes del gènere Faecalibacterium (fílum Firmicutes). Contràriament, els malalts que no van respondre al tractament tenien una diversitat intestinal molt més baixa, però abundant en microorganismes de l'ordre Bacteriodales (fílum Bacteroidetes) (Gopalakrishnan et al., 2018).

Tanmateix, en els pacients amb una microbiota favorable, l'activitat presentadora d'antígens i l'expressió de marcadors de limfòcits T citotòxics estaven potenciades. En un altre estudi, els pacients que acceptaven adequadament el tractament amb anti-PD-1 tenien una microbiota rica en Bifidobacterium longum, Collinsella aerofaciens i Enterococcus faecium (Li et al., 2019).

\subsubsection{Anti-CTLA-4}

La CTLA-4 és una proteïna present als limfòcits T que actua inhibint l'acció d'aquests amb la finalitat de controlar la resposta immunitària. Els tractaments que bloquegen la seva acció estimulen el sistema immunitari a combatre les cèlllules canceroses (Li et al., 2019).

Després del tractament amb anti-CTLA-4, la microbiota dels ratolins va experimentar canvis en la composició: un increment de Bacteroidales (Bacteroides thetaiotaomicron i Bacteroides uniformis) i Burkholderiales (Burkholderia cepacia) i una disminució de Clostridiales (Vétizou et al., 2015; Pitt et al., 2016; Roy i Trinchieri, 2017)many patients inexplicably see no benefit. Mice have been used in two studies to investigate what might be happening. Specific members of the gut microbiota influence the efficacy of this type of immunotherapy (see the Perspective by Snyder et al. .

Davant l'observació d'aquest canvi en el patró de la microbiota intestinal, es va procedir a administrar per via oral bacteris de les espècies incrementades, és a dir, probiòtics orals amb soques bacterianes de les espècies Bacteroides fragilis, Bacteroides thetaiotaomicron i Burkholderia cepacia. En conseqüència, es va evidenciar una notable millora de l'efectivitat terapèutica dels anti-CTLA-4 a causa de l'òptima maduració intratumoral de les cèllules dendrítiques, cosa que va potenciar la resposta dels limfòcits Th1 en els nodes limfàtics del tumor (Vétizou et al., 2015; Roy i Trinchieri, 2017; Li et al., 2019)many patients inexplicably see no benefit. Mice have been used in two studies to investigate what might be happening. Specific members of the gut microbiota influence the efficacy of this type of immunotherapy (see the Perspective by Snyder et al. .

Els probiòtics orals presenten la mateixa efectivitat tant si són espècies bacterianes aillades com si són combinades, malgrat que l'administració conjunta de diferents espècies ha evidenciat una disminució de la progressió del dany intestinal i de l'aparició de colitis relacionada amb el tractament antineoplàstic (Roy i Trinchieri, 2017).

En un estudi amb pacients en tractament amb anti-CTLA-4 es va observar una resistència a desenvolupar colitis en els que tenien una freqüència elevada d'espècies del fílum Bacteroidetes, i ocorria el contrari en el cas de les espècies bacterianes que no expressaven els gens implicats en el transport de poliamines o en la biosíntesi de les vitamines del grup B (Roy i Trinchieri, 2017).

Atès que no tots els bacteris es veuen afectats de la mateixa manera davant d'un antibiòtic, en funció de quin s'administri es modificarà la composició de la microbiota i, per consegüent, l'efectivi- 
tat terapèutica (Elkrief et al., 2019). Per exemple, la vancomicina incrementa l'èxit terapèutic de l'anti-CTLA-4 en ratolins perquè disminueix les espècies bacterianes grampositives i manté les gramnegatives (Bacteroidales i Burkholderiales) (Roy i Trinchieri, 2017).

\subsection{Optimització de la microbiota}

Els bacteris que formen la microbiota poden tenir un impacte directe en l'efectivitat terapèutica de certs medicaments, sobretot en el cas dels antineoplàstics. Per tant, és interessant determinar punts estratègics per optimitzar la microbiota amb l'objectiu d'erradicar el càncer de la manera més idònia possible (Havel, Chowell i Chan, 2019; Li et al., 2019). Aquestes estratègies es poden agrupar en els quatre punts següents (Li et al., 2019):

a) Trasplantament de microbiota fecal (FMT).

b) Administració de probiòtics.

c) Selecció de bacteris beneficiosos mitjançant antibiòtics, prebiòtics, simbiòtics o bacteriòfags.

d) Modificació de factors personals: dieta, exercici i medicació, entre d'altres.

\subsubsection{Selecció de bacteris beneficiosos}

La principal estratègia per potenciar l'activitat de les teràpies antitumorals és eliminar les espècies bacterianes que influeixen negativament en aquests tractaments. Una manera senzilla d'erradicar un bacteri és mitjançant un antibiòtic; ara bé, a causa de la seva baixa especificitat hi ha el risc de derivar en una disbiosi, és a dir, de desequilibrar la microbiota, on novament apareixerien problemes en el funcionament correcte del tractament (Li et al., 2019).

Per això s'ha suggerit la possibilitat de potenciar el creixement de les espècies interessants, terapèuticament parlant, en lloc de suprimir les que influeixen negativament en aquest mateix tractament. La potenciació s'ha de fer mitjançant l'administració de prebiòtics (Li et al., 2019).

Els prebiòtics són components de la dieta que l'aparell digestiu humà no és capaç de metabolitzar sense l'ajuda de la microbiota, com, per exemple, la fibra, la inulina i els galactooligosacàrids (Helmink et al., 2019). Aquestes substàncies faciliten la colonització i l'expansió de determinats bacteris del tracte gastrointestinal. Així mateix, quan són metabolitzats es formen SCFA, que incrementen l'abundància de Bifidobacterium spp., responsables de modular la resposta immunitària i d'ajudar a reduir la mida del tumor en tractaments amb anti-PD-1 (Zitvogel et al., 2017).

Respecte als prebiòtics també hi ha l'inconvenient de la baixa especificitat, i de la mateixa manera s'acabaria potenciant el creixement dels microorganismes que no ens interessa fomentar. Per resoldre aquesta adversitat, se segueixen altres mètodes per seleccionar els bacteris de la microbiota que ens interessen, com, per exemple, els dos següents (Li et al., 2019):

- Simbiòtics: administració de prebiòtics específics per afavorir la colonització del tracte intestinal de les espècies bacterianes beneficioses davant la medicació que s'ha d'aplicar.

- Bacteriòfags: eliminació de les espècies bacterianes perjudicials amb virus específics amb alta selectivitat.

\subsubsection{Trasplantament de microbiota fecal}

El trasplantament de microbiota fecal (FMT) o bacterioteràpia fecal consisteix a transferir l'ecosistema microbià intestinal d'un donant sa a un pacient amb un estat de desequilibri en la microbiota. És una teràpia llargament estudiada en casos de disbiosi intestinal per infeccions provocades per Clostri- 
dium difficile o per malaltia inflamatòria intestinal. Actualment s'està començant a plantejar el seu ús en pacients amb càncer amb la finalitat d'optimitzar el tractament antineoplàstic, com s'ha exposat anteriorment per a la immunoteràpia anti-PD-1/PD-L1 (Helmink et al., 2019; McQuade et al., 2019).

El donador sa ha de ser el més òptim possible; dit d'una altra manera, la seva microbiota ha de tenir una composició molt variada i enriquida amb bacteris beneficiosos, que segons els últims estudis serien Bifidobacterium spp., Akkermansia muciniphilia, Enterococcus hirae i Bacteroides spp. De moment, aquests es consideren capaços de millorar l'efectivitat terapèutica i la immunitat envers el tumor, així com de dificultar el creixement de les cèlllules canceroses (Matson et al., 2018; Li et al., 2019)

Tanmateix, l'FMT no està exempt de riscos, ja que pot contenir microorganismes potencialment patogènics o nocius per als tractaments antitumorals, de manera que també s'ha suggerit seleccionar i administrar únicament els bacteris beneficiosos (Li et al., 2019).

\subsection{Oncomicrobiòtics}

Els resultats obtinguts en els tractaments antineoplàstics són heterogenis i fins fa uns anys aquesta diversitat s'atribuïa només a les característiques intrínseques del tumor. Actualment trobem més evidències sobre la importància de la microbiota i la genètica de l'hoste (McQuade et al., 2019).

Després dels resultats obtinguts en els diferents estudis, es vol potenciar l'administració d'oncomicrobiòtics com a coadjuvants de les teràpies antitumorals; és a dir, fer una selecció acurada dels bacteris i/o dels seus metabòlits amb l'objectiu de convertir-los en una estratègia terapèutica (Pitt $e t$ al., 2016). Quan s'identifica la microbiota més òptima per a un tractament determinat, l'oncomicrobiòtic es formula amb un o més dels components següents (Pitt et al., 2016):

- Bacteris immunògens vius (probiòtics): la colonització intestinal ajuda a restaurar la resposta adaptativa dels limfòcits T contra el tumor.

- Metabòlits bacterians dels bacteris formulats o d'altres.

- Antibiòtics selectius contra bacteris immunosupressors o que potencien el creixement de les cèllulues tumorals.

Per exemple, el 1990 es va aprovar la utilització del bacil de Calmette-Guérin (BCG), una vacuna atenuada de Mycobacterium bovis, com a coadjuvant en el tractament del càncer de bufeta. Després de l'extirpació del tumor, el BCG s'instaura en la bufeta i indueix una resposta immunitària local que redueix la probabilitat de recaiguda (Zitvogel et al., 2017).

\subsubsection{Bacteris immunògens vius}

Els probiòtics són microorganismes vius que proporcionen beneficis als pacients als quals se'ls administren. Són fàcils d'utilitzar i d'obtenir, però tenen l'inconvenient de la dificultat en l'estandardització, en les regulacions del control de qualitat, en la biodisponibilitat i en la modulació de l'objectiu que es pretén aconseguir (McQuade et al., 2019). Alguns probiòtics presenten la capacitat de modular els mecanismes immunitaris davant les cèllules canceroses, raó per la qual també se'ls anomena oncomicrobiòtics (figura 4) (Bultman, 2016; Zitvogel et al., 2017).

Els principals bacteris probiòtics són Lactobacillus spp. Els estudis que s'han centrat en les espècies L. acidophilus, L. casei, L. plantarum i L. rhamnosus, les han relacionat amb la modulació de mecanismes anticancerosos davant l'activació dels limfòcits NK, la maduració de les cèlllules dendrítiques i l'alliberament de ferricrom (pèptid quelant del ferro) (Zitvogel et al., 2017). 


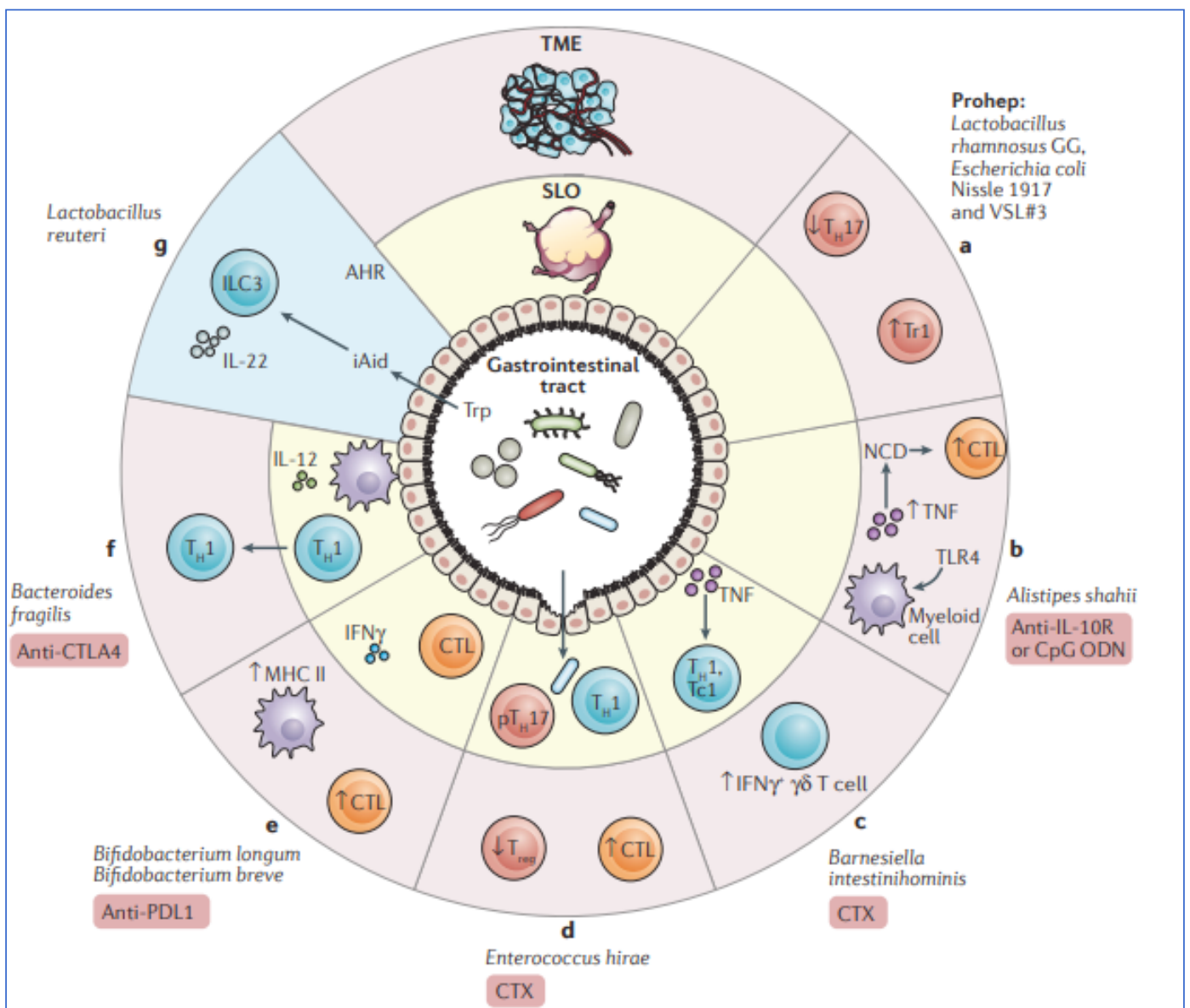

Figura 4. Mecanismes que expliquen l'efecte anticancerós dels oncomicrobiòtics. Les esferes blaves representen els efectes en els òrgans limfoides perifèrics i les esferes vermelles, els efectes en el microambient tumoral (Zitvogel et al., 2017).

El ferricrom secretat per L. casei exerceix un efecte immunosupressor en l'evolució del tumor com a conseqüència de la seva capacitat d'activar l'apoptosi a través de la ruta de senyalització JNK (c-Jun N-terminal Kinase). A més, l'administració continuada de la soca ATCC-PTA-6475 de L. reuteri en ratolins redueix la freqüència de lesions intestinals potencialment canceroses, així com de sarcopènia i atròfia del timus relacionada amb l'edat. També influeix en una major expressió de les cèllules limfoides innates del grup 3 (ILC3s), activades per iAid (immunosuppressive tryptophan catabolite indole-3-aldehyde) i que tenen la funció d'alliberar IL-22, cosa que potencia la resposta als anti-CTL i la vigilància immunològica contra el càncer (Zitvogel et al., 2017).

Per altra banda, el probiòtic Prohep ${ }^{\circledR}$ (L. rhamnosus GG, E. coli Nissle 1917 i VSL\#3 inactivat amb calor) va prevenir la progressió del carcinoma hepatocel-lular en ratolins mitjançant la inhibició dels processos inflamatoris i d'angiogènesi. Aquest probiòtic també va enriquir la microbiota intestinal en Bacteroides fragilis, Alistipes shahii, Parabacteroides distasoni i Akkermansia muciniphila, espècies bacterianes associades amb la reducció de limfòcits Th17 proinflamatoris i amb l'increment de limfòcits antiinflamatoris com els $\mathrm{T}_{\text {reg }}$ i els $\operatorname{Tr} 1$ (limfòcit $\mathrm{T}$ regulador de tipus 1 ).

Pel que fa a Bacteroides fragilis, les soques enterotoxígenes es relacionen amb la carcinogènesi perquè afavoreixen la maduració dels limfòcits Th17 proinflamatoris. Contràriament, Burkholderia cepacia i les soques no enterotoxígenes de Bacteroides fragilis podrien millorar l'èxit terapèutic en els tractaments amb anti-CTLA-4 gràcies al fet que promouen la síntesi de IL-12 i la maduració intratumoral de les cèllulues dendrítiques, cosa que permet l'expansió dels limfòcits T anticancerosos. És el mateix mecanisme que el de Bifidobacterium longum i B. breve en el cas dels anti-PD-L1 (Zitvogel et al., 2017). 
En darrer lloc, altres espècies que també tenen efectes anticancerosos són Barnesiella intestinihominis i Enterococcus hirae. Ambdós bacteris actuen en els òrgans limfoides perifèrics (ganglis limfàtics, melsa, etc.): incrementen el nombre de limfòcits $\mathrm{CD} 4^{+}$i $C D 8^{+}$i de cèlllules $\mathrm{T} \gamma \delta$ en melsa $\mathrm{i}$ tumor. En el cas de B. intestinihominis, com que hi ha més cèllules $\mathrm{T} \gamma \delta$, es dona una major producció de IFN $\gamma$ i IL-17, que faciliten la immunitat envers el càncer.

S'ha vist en ratolins que la combinació de B. intestinihominis amb CTX redueix el creixement tumoral com a conseqüència de l'activació de les rutes que involucren limfòcits Th1, limfòcits T CD8 ${ }^{+}$ de tipus 1, TNF i INF $\gamma$. D'altra banda, Enterococcus hirae influeix en l'alliberament de limfòcits T CD4 ${ }^{+}$ $\mathrm{T}_{\mathrm{H}} 17$ i $\mathrm{T}_{\mathrm{H}} 1$, a més de disminuir els limfòcits $\mathrm{T}_{\text {reg }}$ (Zitvogel et al., 2017; Raza et al., 2019).

\subsubsection{Metabòlits bacterians}

Els bacteris sintetitzen certs productes que poden afectar la supervivència i l'evolució de les cèlllules tumorals i l'efectivitat terapèutica dels antineoplàstics. Dins d'aquests productes trobem les toxines relacionades amb propietats anticanceroses, els lligands dels receptors que reconeixen patrons (PRRS) que afecten la resposta immunitària i els metabòlits capaços de modular el metabolisme de l'hoste (figura 5) (Zitvogel et al., 2017).

Com a exemples de toxines sintetitzades per bacteris es troben la doxorubinina (antibiòtic sintetitzat per Streptomyces spp.) i la LTX-35. D'una banda, la doxorubicina és un fàrmac utilitzat freqüentment en quimioteràpia antitumoral, ja que indueix la mort celllular immunògena. D'altra banda, es va desenvolupar un pèptid sintètic anomenat LTX-315 amb la capacitat de destruir les cèllulues tumorals per la lisi dels seus mitocondris (mort celllular necròtica) (Zitvogel et al., 2017).
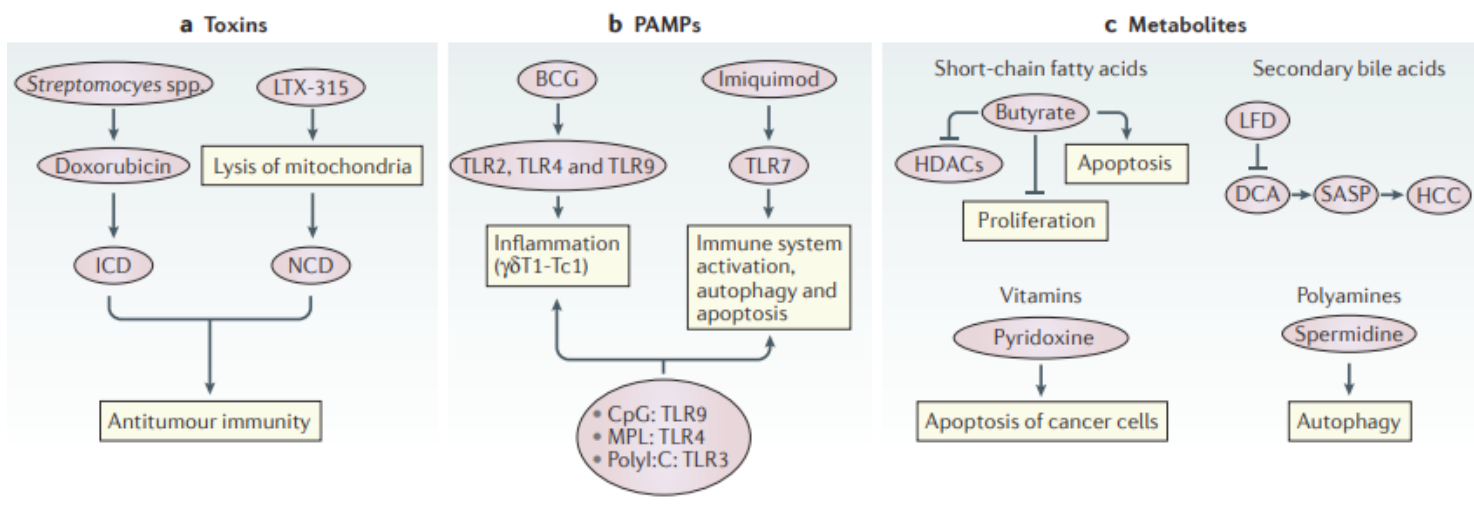

Figura 5. Els efectes anticancerosos dels metabòlits bacterians (Zitvogel et al., 2017).

Els PRR reconeixen PAMP, encara que també poden disposar de lligands endògens. Un dels PAMP més coneguts és el lipopolisacàrid bacterià (LPS), component de la membrana externa dels bacteris gramnegatius que interacciona amb el receptor TLR4 i estimula la resposta inflamatòria. El TLR4 és essencial per l'òptima resposta antitumoral del BCG. També cal esmentar els agonistes dels receptors TLR, com és el cas de l'imiquimod, agonista del receptor TLR7 administrat en casos de queratosi actínica i que presenta la capacitat d'estimular el sistema immunitari i l'apoptosi (Zitvogel et al., 2017).

Finalment, els metabòlits bacterians poden arribar a tenir un paper molt important en el metabolisme humà. Com a metabòlits importants es troben els SCFA, els àcids biliars secundaris, les vitamines i les poliamines.

Els SCFA, com l'acetat, el butirat i el propionat, són sintetitzats en el còlon a partir de la fibra i els polisacàrids. El propionat i el butirat intervenen en la diferenciació i la síntesi de limfòcits $\mathrm{T}_{\mathrm{reg}}$ mentre que la vitamina piridoxina i la poliamina esperimidina afavoreixen l'apoptosi i l'autofàgia de 
les cèlllules canceroses. Els gèneres que més els sintetitzen són Eubacterium, Roseburia, Faecalibacterium i Coprococcus (Bultman, 2016; Zitvogel et al., 2017; Chen, Zhao i Vitetta, 2019).

\section{Conclusions}

- La variació en la composició, tant qualitativa com quantitativa, dels bacteris formadors de la microbiota, modifica els processos implicats en la inflamació, la carcinogènesi i la resposta als tractaments antitumorals.

- L'inici i el desenvolupament del càncer colorectal poden estar relacionats amb disbiosi, inflamació crònica, resposta immunitària deficient i síntesi de metabòlits tòxics.

- Escherichia coli, Bacteroides fragilis, Citrobacter rodentium i Fusobacterium nucleatum són oncomicrobis que estan directament relacionats amb el càncer de còlon.

- La microbiota pot modificar la farmacocinètica, l'activitat i la toxicitat dels fàrmacs utilitzats en quimioteràpia i immunoteràpia antitumoral.

- Les estratègies actuals per modificar la microbiota amb l'objectiu d'optimitzar el tractament antitumoral es basen en el trasplantament de microbiota fecal, la selecció de bacteris beneficiosos, l'administració de probiòtics i la modificació de la dieta.

- Els oncomicrobiòtics es formulen amb bacteris immunògens vius o inactivats per calor, metabòlits bacterians i/o antibiòtics selectius contra espècies bacterianes que potencien l'evolució del tumor.

- Lactobacillus spp., Burkholderia cepacia, Bifidobacterium spp., Barnesiella intestinihominis, Enterococccus hirae i les soques no enterotoxígenes de Bacteroides fragilis són bacteris immunògens amb capacitat d'optimitzar la resposta dels tractaments antineoplàstics $i$, per tant, oncomicrobiòtics.

- La relació entre la microbiota i el càncer és un camp emergent que requereix més estudis per establir una base teòrica més fiable.

\section{Bibliografia}

Ahmed, I., Umar, S. (2018) «Microbiome and Colorectal Cancer». Current Colorectal Cancer Reports, 14(6), pp. 217-225.

BleKhman, R., Goodrich, J., HuANG, K. et al. (2015) «Host genetic variation impacts microbiome composition across human body sites». Genome Biology, 16(1), p. 191.

Bultman, S. (2016) «The microbiome and its potential as a cancer preventive intervention». Seminars in Oncology, 43(1), pp. 97-106.

Chen, J., Zhao, K., VitetTA, L. (2019) «Effects of Intestinal Microbial-Elaborated Butyrate on Oncogenic Signaling Pathways». Nutrients, 11(5), p. 1026.

ELKRIEF, A., El RAICHANI, L., RichaRD, C. et al. (2019) «Antibiotics are associated with decreased progression-free survival of advanced melanoma patients treated with immune checkpoint inhibitors». Oncoimmunology, 8(4), e1568812.

Faith, J., Guruge, J., Charbonneau, M. et al. (2013) «The Long-Term Stability of the Human Gut Microbiota». Science, 341(6141), p. 1237439.

GopalaKRISHNAN, V., SPENCER, C., NeZI, L. et al. (2018) «Gut microbiome modulates response to anti-PD-1 immunotherapy in melanoma patients». Science, 359(6371), pp. 97-103.

HAVEL, J., CHOWELL, D., CHAN, T. (2019) «The evolving landscape of biomarkers for checkpoint inhibitor immunotherapy». Nature Reviews Cancer, 19(3), pp. 133-150.

Helmink, B., Khan, M., HeRmann, A. et al. (2019) «The microbiome, cancer, and cancer therapy». Nature Medicine, 25(3), pp. 377-388.

JiN, Y., LIU, Y., ZHAO, L. et al. (2018) «Gut microbiota in patients after surgical treatment for colorectal cancer». Environmental Microbiology, 21(2), pp. 772-783. 
LI, W., DenG, Y., Chu, Q. et al. (2019) «Gut microbiome and cancer immunotherapy». Cancer Letters, 447, pp. 41-47.

Markowski, M., Boorjian, S., Burton J. et al. (2019) «The Microbiome and Genitourinary Cancer: A Collaborative Review». European Urology, 75(4), pp. 637-646.

MAtson, V., FEsSler, J., BAO, R. et al. (2018) «The commensal microbiome is associated with anti-PD-1 efficacy in metastatic melanoma patients». Science, 359(6371), pp. 104-108.

Mcquade, J., DANiel, C., Helmink, B. et al. (2019) «Modulating the microbiome to improve therapeutic response in cancer». The Lancet Oncology, 20(2), pp. e77-e91.

Misch, E., SAFdAR, N. (2019) «Clostridioides difficile Infection in the Stem Cell Transplant and Hematologic Malignancy Population». Infectious Disease Clinics of North America, 33(2), pp. 447-466.

PitT, J., Vetizou, M., Waldschmitt, N. et al. (2016) «Fine-Tuning Cancer Immunotherapy: Optimizing the Gut Microbiome». Cancer Research, 76(16), pp. 4602-4607.

RAzA, M., Gul, K., ARShAD, A. et al. (2019) «Microbiota in cancer development and treatment». Journal of Cancer Research and Clinical Oncology, 145(1), pp. 49-63.

Rooks, M., GARRETT, W. (2016) «Gut microbiota, metabolites and host immunity». Nature Reviews Immunology, 16(6), pp. 341-352.

Routy, B., ChAtelier, E., DerosA, L. et al. (2018) «Gut microbiome influences efficacy of PD-1-based immunotherapy against epithelial tumors». Science, 359(6371), pp. 91-97.

Roy, S., TRINCHIERI, G. (2017) «Microbiota: a key orchestrator of cancer therapy». Nature Reviews Cancer, 17(5), pp. 271-285.

VÉTIZou, M., PitT, J., DAILlÈre, R. et al. (2015) «Anticancer immunotherapy by CTLA-4 blockade relies on the gut microbiota». Science, 350(6264), pp. 1079-1084.

Wong, S., Kwong, T., Wu, C. et al. (2019) «Clinical applications of gut microbiota in cancer biology». Seminars in Cancer Biology, 55, pp. 28-36.

Zitvogel, L., DAillère, R., Roberti, M. et al. (2017) «Anticancer effects of the microbiome and its products». Nature Reviews Microbiology, 15(8), pp. 465-478. 